\title{
The volatile emission of honeybee queens (Apis mellifera L)
}

\author{
RFA Moritz ${ }^{1 *}$, RM Crewe 2 \\ ${ }^{\prime}$ Bayerische Landesanstalt für Bienenzucht, Burgbergstraße 70, 8520 Erlangen, Germany; \\ ${ }^{2}$ University of the Witwatersrand, Department of Zoology, Jan Smuts Ave 1, \\ Johannesburg 2001, Republic of South Africa
}

(Received 27 September 1990; accepted 8 March 1991)

\begin{abstract}
Summary - The volatile compounds released by honeybee queens (Apis mellifera $L$ ) were trapped from the vapour phase with an absorbent (Tenax TA) and extracted in hexane. Heads and tergites of these queens were extracted in dichloromethane. After gas chromatography, the chromatograms were statistically analyzed and compared. Seventy-three percent of the compounds in head extracts and $56 \%$ of tergal compounds were found in the trapped volatile signal. There were, however, substantial quantitative differences between the actual amounts of individual compounds found in the trap and in head and tergite extracts respectively. For example, little $(\mathrm{E})$-9-oxodec-2-enoic acid (9-ODA), the classical queen substance and predominant compound of head extracts, was found in the vapour phase. Tergal signals and mandibular gland secretions contributed equally to the total pheromone blend in the volatile signal. Furthermore, compounds not present in either the tergal or head extracts were found.
\end{abstract}

Apis mellifera / queen substance / volatile semiochemical / mandibular gland / tergal gland

\section{INTRODUCTION}

The pheromones produced by the queen are of crucial importance in the biology of honeybees. Outside the nest cavity some of them function in the vapour phase as a sex attractant during mating (Gary, 1962; Butler and Fairey, 1964) and are important in swarm orientation and stabilization (Avitabile et al, 1975; Winston et al, 1982). Inside the colony, workers are most strongly affected by queen pheromones if they have direct contact with the queen (Butler, 1954; Verheijen-Voogd, 1959). The queen pheromones which are distributed in the colony by messenger workers (Velthuis, 1972; Seeley, 1979; Ferguson and Free, 1980) inhibit rearing of new queens (Butler, 1961; Velthuis, 1970) and ovary development in workers (Pain, 1961; Butler and Fairey, 1963; Velthuis, 1972). The classical queen substance, (E)-9-oxodec-2-enoic acid (9ODA) is the major component of the mandibular gland secretions. Highly specific receptor cells in the antennae of workers and drones have been shown to be important for 9ODA perception (Beetsma and Schoonhoven, 1966; Kaissling and Renner, 1968; Adler et al, 1973). Though 9ODA alone releases all typical behavioural responses of drones and workers to

\footnotetext{
* Correspondence and reprints, current address: Department of Genetics, University of Natal, PO Box 375, Pietermaritzburg 3200, South Africa
} 
queen pheromones (Velthuis, 1985), the complete bouquet of all semiochemicals of the mandibular glands proved to be biologically more active than isolated compounds (Slessor et al, 1988). Queen pheromones other than those of the mandibular glands are also important cues for worker honeybees. For example, the tergal pheromones are known to attract drones during mating (Renner and Vierling, 1977).

Though the volatile signal is of crucial importance for the workers whenever direct contact perception is impossible, it has never been chemically analyzed. Concern about the volatile components of pheromonal secretions has frequently been expressed, particular with respect to blend compositions in the vapour phase (Olsson et al, 1983). Compounds which are minor components of extracts could become predominant in the vapour phase if their volatility is high and vice versa. Furthermore, the contribution of other glandular sources such as the tergal glands to the volatile signal seems to be important. In this paper we therefore study how the semiochemicals of the mandibular and the tergal glands contribute to the actual composition of the volatile compounds of honeybee queens in the vapour phase.

\section{MATERIALS AND METHODS}

Twenty-three honeybee queens (Apis mellifera capensis) were reared using routine bee breeding techniques (Ruttner, 1980). A few days before emergence, the queen cells were introduced into cages with small groups of freshly emerged workers (Apis mellifera scutellata, 100 per cage) all from 1 colony. The cages were kept at $30^{\circ} \mathrm{C}$ in the dark with pollen and candy supplied ad libitum. After $8 \mathrm{~d}$ the queens are transferred to an extraction apparatus similar to that of Moritz and Crewe (1988b).
All glassware of the extraction apparatus was washed 3 times in hexane and baked in an oven at $350{ }^{\circ} \mathrm{C}$ for at least $2 \mathrm{~h}$ before use. The queens were placed in $5-\mathrm{ml}$ glass vials with wide air inlets (16 $\mathrm{mm}$ diameter), ground glass joints and narrow outlets (1 $\mathrm{mm}$ diameter) (fig 1). A glass cartridge filled with activated charcoal was attached to the air inlet, to purify the air

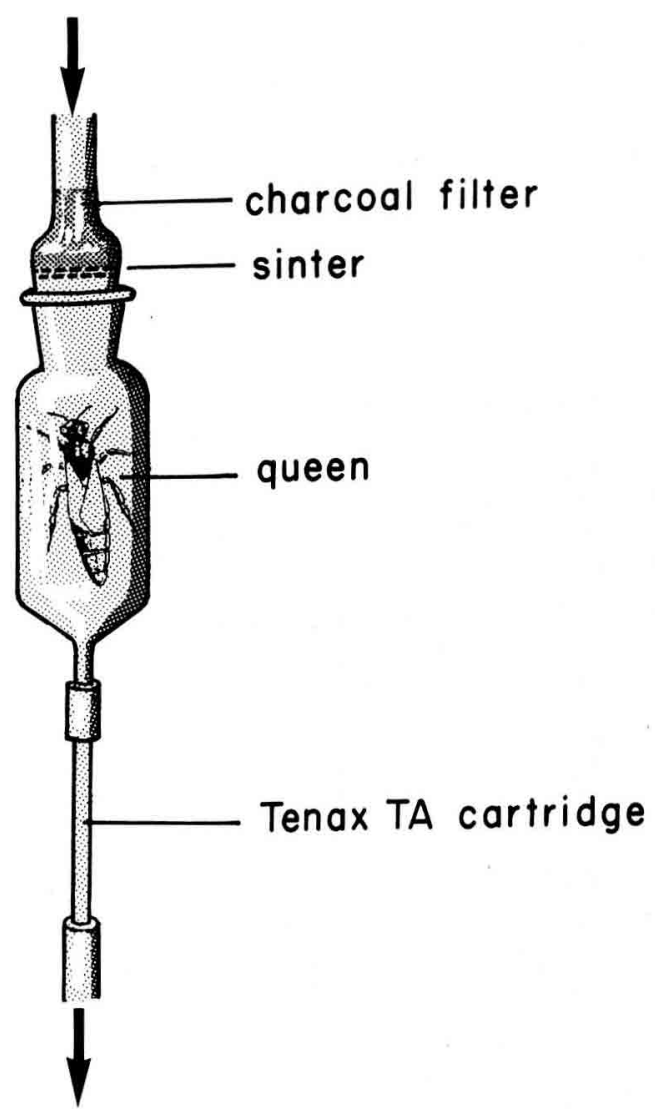

Fig 1. Apparatus to absorb volatile signals released by the honeybee queen. Air is pumped through a charcoal filter placed on a glass sinter in the air inlet. The filtered air passes through the queen chamber and volatile compounds released by the queen are absorbed on the Tenax in the cartidge connected to the air outlet. The cartridge is closed on both ends with 2 siliconized glass wool plugs. A suction pump moves the air a flow rate of $25 \mathrm{ml} / \mathrm{min}$. 
entering the system. An absorbent cartridge was attached to the outlet. It consisted of a small glass tube ( $5 \mathrm{~mm}$ diameter, $50 \mathrm{~mm}$ length) filled with $50 \mathrm{mg}$ Tenax RA. This absorbent consists of a porous polymer based on 2,6-diphenyl-pphenylene oxide also used as column packing material. The Tenax was kept in place by means of siliconized glass wool plugs. The open end of the cartridge was connected to a suction pump. Air was moved through the system at a rate of $25 \mathrm{ml} / \mathrm{min}$. After $2 \mathrm{~h}$ the cartridge was removed, and sealed in a glass vial at $-20^{\circ} \mathrm{C}$ before further analysis. In spite of the evidence given by Bertsch et al (1975) regarding the capacity of Tenax traps, the possibility of breakthrough of compounds from the trap was checked by placing a second trap after the first and running the system under the same conditions as above. Blank trials (the above system without the queen) were run to control for artifacts due to air or solvent contamination.

After trapping the volatile compounds, the queens were decapitated and single heads were extracted in $1.5 \mathrm{ml}$ dichloromethane. The tergites were carefully removed from the abdomen and also placed in $1.5 \mathrm{ml}$ dichloromethane.

The volatile compounds which were trapped on the Tenax were extracted 3 times with the same volume of $4 \mathrm{ml}$ hexane. The samples were reduced to $1.5 \mathrm{ml}$ with a stream of nitrogen and kept in teflon sealed glass vials.

For gas chromatography all samples were concentrated to $20-\mu$ l volume under nitrogen. Samples of $1 \mu \mathrm{l}$ were coinjected with $0.5 \mu \mathrm{l}$ hexane as solvent plug via a split-splitless inlet into a capillary gas chromatograph (HP-5890). The apparatus was fitted with a methyl silicone coated fused silica column (25 m length; $0.32 \mathrm{~mm}$ diameter; carrier gas $\mathrm{H}_{2}$ at a flow rate of $1.2 \mathrm{ml} /$ min). The oven temperature was linearly increased at a rate of $6{ }^{\circ} \mathrm{C} / \mathrm{min}$ from $40^{\circ} \mathrm{C}$ to $260^{\circ} \mathrm{C}$. The chromatogram was recorded on line with a computing integrator (HP 3393).

\section{RESULTS}

Figure 2 shows 3 typical chromatograms of head, tergite and trap extract. Many of the compounds found in the head and tergite extracts are also found in the trapped vola- tile signal. The chromatograms of the blank runs and of the breakthrough tests did not show any of the marked peaks. Of the 16 major compounds in the tergite extracts, 10 were found in the Tenax TA trap. Eleven of the 14 head extract compounds could be recovered from the absorbent. Four peaks were found in the traps which did not correspond to any of the peaks in head or tergite extract chromatograms.

Though there are strong qualitative similarities between the volatile trapped compounds and extracts of body parts, there are substantial quantitative differences. Table I shows the relative contribution of each peak to the total volatile bouquet. 9ODA for example, which is the major peak (cf in fig 2) of the head extract, contributes very little to the trapped compounds. Some tergal compounds (eg peaks $A$ and $G$ ) contribute much more strongly to the volatile bouquet than 9 ODA does. Furthermore, the 4 long chain acids (hexadecenoic to octadecanoic acid: H, I, $\mathrm{J}, \mathrm{K}$ ) are found in surprisingly high concentrations in the Tenax traps, considering their low volatility. There is no significant correlation between the quantitative composition of extracted head ( $r=0.08$, ns) and tergites ( $r=-0.007$, ns) and the volatile trapped compounds.

\section{DISCUSSION}

In most cases, the trapped volatile signal gives a truer representation of the quantitative relationships of the components of an emitted signal than the analysis of glandular extracts (Shani and Lacey, 1984; Heath et al, 1986). As for other insects, Tenax (Cross, 1980) proved to be an adequate adsorbant for trapping the volatile emission of honeybee queens and comparing it with the secretions of 2 glands. The volatile compounds released by the queen differ in 

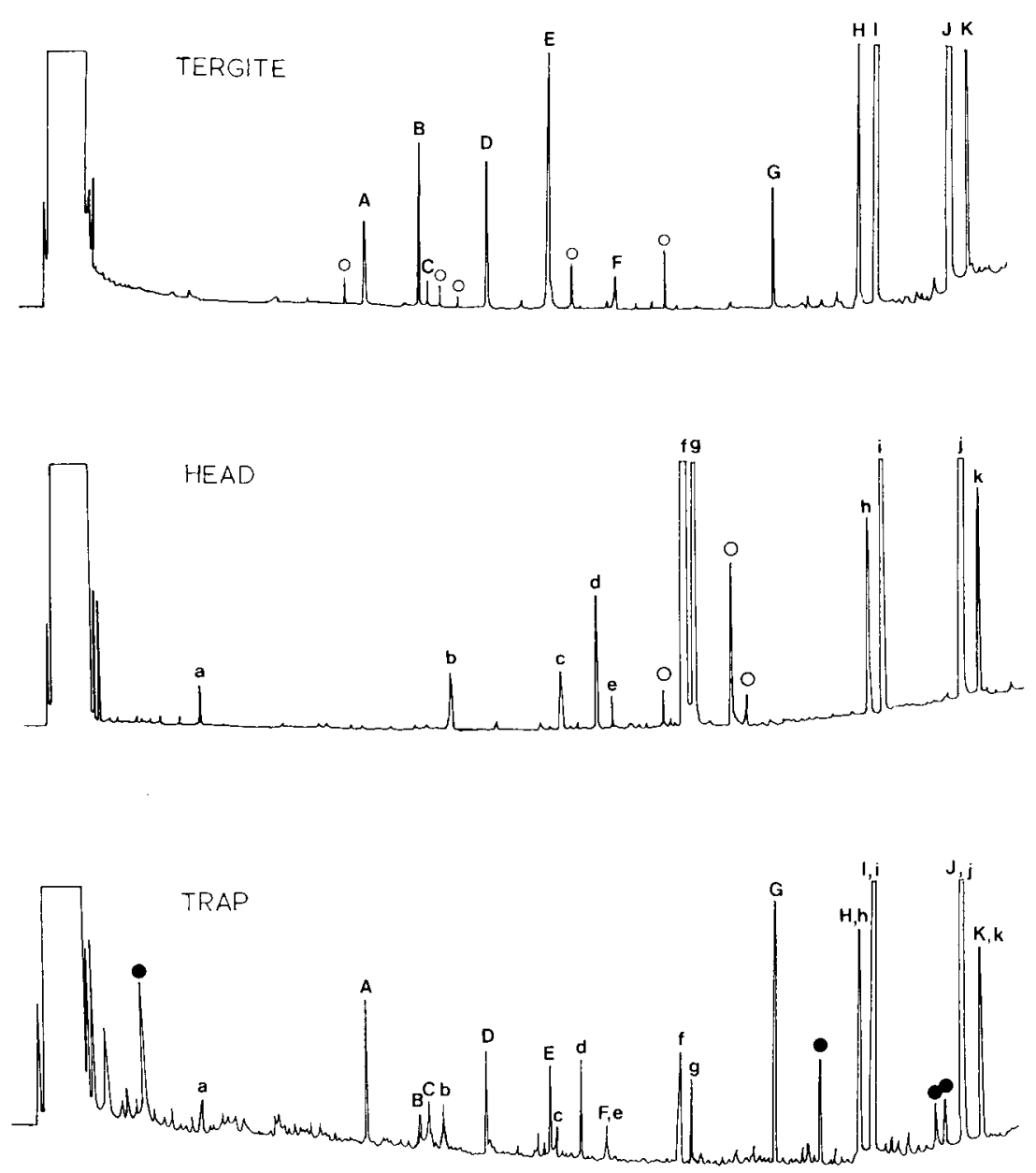

Fig 2. Typical gas chromatograms of the tergite (Tergite) and head extracts (HEAD), the volatile signal trapped on Tenax TA (TRAP) and the blank (BLANK). The lettering characterizes compounds common in head (small letters) or tergite extracts (capitals) and the trapped signal. Peaks in head and tergite chromatograms marked with open circles are not present in the volatile signal. Compounds marked with black circles were present in the volatile signal but not in the extracts; $f=9 O D A$, $g=9 H D A)$.

many aspects from gland extracts (Crewe, 1982; Velthuis, 1985). Many compounds found in head and tergite extracts are present in the trapped compound bouquet, but others are not, and the quantitative composition is completely different. Com- pounds not found in the extracts were captured in the Tenax trap. These additional compounds are likely to be products of glands not extracted in our procedure, for example, the tarsal Arnhard glands which produce the footprint pheromone (Lensky 
Table I. Contributions to total the chemical bouquet (\% $\%$ SE of total signal) of those compounds in head and tergite extracts which were trapped in Tenax. Compounds as in figure 2.

\begin{tabular}{lccc}
\hline & \multicolumn{3}{c}{$\%$ Contribution to total bouquet } \\
\cline { 2 - 4 } Peak & Head extract & Tenax TA trap & Tergite extract \\
\hline & & & \\
a & $2.96 \pm 1.23$ & $1.31 \pm 0.70$ & - \\
A & - & $5.51 \pm 1.57$ & $1.45 \pm 0.56$ \\
B & - & $1.45 \pm 0.21$ & $6.38 \pm 0.99$ \\
C & - & $1.22 \pm 0.24$ & $5.55 \pm 0.97$ \\
b & $1.57 \pm 0.68$ & $2.36 \pm 0.79$ & - \\
D & - & $1.75 \pm 0.40$ & $3.32 \pm 0.51$ \\
E & - & $2.78 \pm 0.47$ & $16.22 \pm 2.83$ \\
C & $0.92 \pm 0.23$ & $1.13 \pm 0.82$ & - \\
d & $1.55 \pm 0.41$ & $3.04 \pm 0.70$ & - \\
e, F & $0.15 \pm 0.04$ & $2.65 \pm 0.71$ & $3.50 \pm 1.47$ \\
f & $48.66 \pm 6.02$ & $3.41 \pm 0.62$ & - \\
g & $11.14 \pm 2.41$ & $3.22 \pm 0.49$ & - \\
G & - & $4.65 \pm 1.14$ & $3.38 \pm 1.05$ \\
h, H & $2.72 \pm 0.53$ & $5.51 \pm 1.84$ & $8.89 \pm 2.01$ \\
i, I & $17.16 \pm 5.79$ & $24.66 \pm 6.54$ & $25.76 \pm 5.56$ \\
J, J & $2.82 \pm 0.67$ & $9.53 \pm 3.43$ & $12.87 \pm 2.67$ \\
K, K & $5.22 \pm 2.81$ & $7.30 \pm 3.62$ & $8.43 \pm 1.97$ \\
Not trapped & 5.13 & & 4.25 \\
& & & \\
\hline
\end{tabular}

and Slabezki, 1981). Clearly, the volatile emission of honeybee queens consists of many compounds which have yet to be biologically tested. This may explain why gland extracts or synthetic pheromone blends have been less active than odours of live queens in bioassays (Moritz and Crewe, 1988a).

The relative contribution of the mandibular gland secretions to the total volatile emission was surprisingly small. 9Hydroxy-(E)-2-decenoic acid (9HDA, peak $\mathrm{g})$, which is considered to be a crucial mandibular gland secretion and is more volatile than 9ODA, is only a minor component of the volatile signal. Apparently not only the volatility of the compound determines its release into the vapour phase. 9ODA contributes only $6.8 \%$ of the com- pounds to the live queen signal instead of $58.7 \%$ to the mandibular gland extract. Nevertheless, 9ODA has been repeatedly shown to be the major biologically active compound in the vapour phase (Avitabile et al, 1975; Moritz and Crewe, 1988a). Apparently it is not the actual concentration in the extracts which tells us about the importance of particular components. A low threshold on the receiver side, for example via highly sensitive specialist receptors, can compensate for low concentrations of semiochemicals as is best documented for Bombyx mori (Butenandt et al, 1959).

The volatile components trapped on $\mathrm{Te}$ nax are not composed predominantly of mandibular gland secretions. The contribution of components from the tergites is equally significant. Volatile tergal signals 
are important for retinue behaviour, mating (Velthuis, 1985) and queen recognition (Moritz and Crewe, 1988b). Because of the multiple functions of the tergal semiochemicals, there is a demand for more research on these signals and those substances present in the volatile emission but not secreted by either the tergal or the mandibular glands.

We suggest that in future experiments with queen equivalents of synthetic pheromones, the signal composition in the vapour phase rather than that of gland extracts should be used. We could not find any quantitative correlation between the compound bouquet of gland extracts and the volatile emission of live queens. However, only the latter represents the actual biologically active semiochemical blend under many natural conditions. Our results support the hypothesis of Velthuis (1988) that the release of semiochemicals into the vapour phase is not simply a function of their volatility, but the texture and chemistry of the body surface is crucial for the release of pheromones. Active cuticular transport of queen pheromones, as shown by Butler et al (1974) strongly affects the release of semiochemicals. We therefore conclude that the interpretation of experiments, in which gland extract equivalents on small pieces of glass or filter paper are presented to workers as "pseudoqueens", should be made with caution.

\section{ACKNOWLEDGMENTS}

We thank the Bayerisches Staatsministerium für Ernährung, Landwirtschaft und Forsten, the CSIR, the Deutsche Forschungs Gemeinschaft and the University of the Witwatersrand for financial support of this study.
Résumé - Les émissions volatiles de la reine d'abeilles (Apis mellifera $\mathrm{L}$ ). Les composés volatils émis par des reines d'abeilles (Apis mellifera $L$ ) ont été piégés par headspace sur un absorbant (Tenax TA) et extraits à l'hexane. Les têtes et les tergites des mêmes reines ont été extraits au dichlorométhane. Les extraits ont été passés en chromatographie en phase gazeuse et les chromatogrammes obtenus analysés et comparés. Soixante treize pour cent des composés présents dans les extraits de tête et $56 \%$ des composés des extraits de têtes et de tergites ont été respectivement retrouvés dans le signal volatil piégé. Il y avait néanmoins des différences quantitatives importantes entre les composés piégés et ceux présents dans les extraits de têtes et de tergites. On a, par exemple, trouvé peu d'acide céto- 9 décène-2 oïque (9-ODA), composé prédominant des extraits de têtes, dans la phase vapeur. Les composés des extraits de tergites et des sécrétions des glandes mandibulaires contribuent de façon équivalente au signal volatil global. Par ailleurs, on a trouvé des composés qui n'étaient présents ni dans les extraits de têtes ni dans ceux de tergites.

Apis mellifera / médiateur chimique / substance royale / glande tergale / glande mandibulaire / composé volatil

\section{Zusammenfassung - Volatile Emissio- nen der Bienenkönigin (Apis mellifera} L). Das volatile Signal, das von Bienenköniginnen (Apis mellifera $L$ ) freigesetzt wird, wurde in der Gasphase mit Tenax TA absorbiert (Abb 1) und in Hexan extrahiert. Köpfe und Tergite dieser Königinnen wurden in Dichlormethan extrahiert. Alle 
Extrakte wurden gaschromatographisch analysiert. $73 \%$ der Substanzen, die in Kopfextrakten gefunden wurden und $56 \%$ der tergalen Substanzen konnten im volatilen Signal wiedergefunden werden (Abb 2). Es ergaben sich jedoch erhebliche quantitative Veränderungen in der Zusammensetzung des volatilen Signals im Vergleich zu Kopf- und Tergitextrakten. So wurde zB 9-Oxodecensäure in wesentlich schwächeren relativen Konzentrationen (Anteil am Gesamtsignal) als in Kopfextrakten gefunden. Stoffe der Tergitextrakte trugen gleich stark zur Zusammensetzung des volatilen Signales bei wie die Sekrete der Mandibeldrüsen. Zudem wurden Stoffe in der Falle absorbiert, die weder in Tergitnoch in Kopfextrakten nachzuweisen waren.

\section{Bienenkönigin / volatiler Stoff / Mandi- beldrüse / Taschendrüse}

\section{REFERENCES}

Adler VE, Doolittle RE, Shimanuki H, Jacobson $M$ (1973) Electrophysiological screening of queen substance and analogous for attraction to drone, queen, and worker honey bees. $J$ Econ Entomol 66, 33-36

Avitabile AR, Morse RE, Boch R (1975) Swarming honeybees guided by pheromones. Ann Entomol Soc Am 68, 1079-1082

Beetsma J, Shoonhoven LM (1966) Some chemosensory aspects of the social relations between the queen and the worker in the honeybee. Proc K Ned Akad Wet Ser C Biol Med Sci 69, 645-647

Bertsch W, Anderson E, Holzer G (1975) Trace analysis of organic volatiles in water by gas chromatography - mass spectrometry with glass capillary columns. J Chromatogr 112 , 701-710

Butenandt A, Beckmann R, Stamm D, Hecker E (1959) Über den Sexual-Lockstoff des Seidenspinners Bombyx mori. Reindarstellung und Konstitution. $Z$ Naturforsch 14, 283-284
Butler CG (1954) The method and importance of the recognition by a colony of honeybees (Apis mellifera) of the presence of its queen. Trans $R$ Soc Lond 105, 11-29

Butler CG (1961) The scent of queen honey bees (Apis mellifera) that causes partial inhibition of queen rearing. $J$ Insect Physiol 15, 237-244

Butler CG, Fairey EM (1963) The role of the queen in preventing oogenesis in worker honeybees. J Apic Res 2, 14-18

Butler CG, Fairey EM (1964) Pheromones of the honeybee: biological studies of the mandibular gland secretion of the queen. $J$ Apic Res 3, 65-76

Butler CG, Callow RK, Greenway AR, Simpson J (1974) Movement of the pheromone 9oxodec-2-enoic acid, applied to the body surface of honeybees. Entomol Exp Appl 17, 112-116

Crewe RM (1982) Compositional variability: the key to the social signals produced by honeybee mandibular glands. In: The Biology of Social Insects (Breed MD, Michener CD, Evans HE, eds) Westview Press, Boulder CO, 318-322

Cross JH (1980) A vapour collection and thermal desorption method to measure semiochemical release rates from controlled release formulations. J Chem Ecol 6, 781-787

Ferguson AW, Free JB (1980) Queen pheromone transfer within honeybee colonies. Physiol Entomol 5, 359-366

Gary NE (1962) Chemical mating attractants in the queen honey bee. Science 136, 773-774

Heath RR, Teal PEA, Tumlinson JH, Mengelkock LJ (1986) Prediction of release ratios multicomponent pheromones from rubber septa. J Chem Ecol 12, 2133-2143

Kaissling KE, Renner M (1968) Antennale Rezeptoren für Queen Substance und Sterzelduft bei der Honigbiene. $Z$ Vergl Physiol 59, 357-361

Lensky $Y$, Slabezki $Y$ (1981) The inhibitory effect of the queen bee (Apis mellifera $L$ ) footprint pheromone on the construction of swarming cups. $J$ Insect Physiol 27, 313-323

Moritz RFA, Crewe RM (1988a) Reaction of honeybee workers (Apis mellifera L) to fatty acids in queen signals. Apidologie 19, 333342 
Moritz RFA, Crewe RM (1988b) Chemical signals of queens in kin recognition of honeybees (Apis mellifera L). J Comp Physiol A $164,83-89$

Olsson AM, Jönsson JA, Thelin B, Liljefors T (1983) Determination of the vapour pressures of moth sex pheromone components by a gas chromatographic method. $J$ Chem Ecol 9, 375-385

Pain $J$ (1961) Sur la phéromone des reines d'abeille et ses effets physiologiques. Ann Abeille 4, 73-153

Renner M, Vierling G (1977) Die Rolle des Taschendrüsenpheromons beim Hochzeitsflug der Bienenkönigin. Behav Ecol Sociobiol 2, 329-338

Ruttner F (1980) Königinnenzucht. Apimondia, Bucharest

Seeley TD (1979) Queen substance dispersal by messenger workers in honeybee colonies. Behav Ecol Sociobiol 5, 391-415

Shani A, Lacey MJ (1984) Convenient method applicable to single insects for collection and measurement of blend ratios of airborne pheromones from artificial sources. $J$ Chem Ecol 10, 1677-1692
Slessor KN, Kaminski LA, King GGS, Borden $\mathrm{JH}$, Winston ML (1988) Semiochemical basis of retinue response to queen honey bees. Nature (Lond) 332, 354-356

Velthuis HHW (1970) Queen substances from the abdomen of the honey bee queen. $Z$ Vergl Physiol 70, 210-222

Velthuis HHW (1972) Observations on the transmission of queen substances in the honey bee colony by attendants of the queen. Behaviour 41, 105-129

Velthuis HHW (1985) The honeybee queen and the social organization of her colony. In: Experimental Behavioral Ecology and Sociobiology (Hölldobler B, Lindauer M, eds) Gustav Fischer, Stuttgart, 343-357

Velthuis HHW (1988) Chemical signals and dominance communication in the honeybee Apis mellifera (Hymenoptera: Apidae). Entomol Gen 15, 83-90

Verheijen-Voogd C (1959) How worker bees perceive the presence of their queen. $J$ Vergl Physiol 41, 527-582

Winston ML, Slessor KN, Smirle MJ, Kandil AA (1982) The influence of a queen-produced substance, 9HDA, on swarm clustering behavior in the honeybee Apis mellifera $L$. $J$ Chem Ecol 8, 1283-1288 